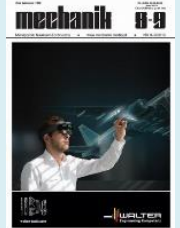

Authors: Daniel Grochała, Emilia Bachtiak-Radka, Sara Dudzińska

Title of article: „Zmiany powierzchni przedmiotów obrabianych na twardo przez frezowanie i nagniatanie” (“The changes of the workpiece surfaces by hard machining by milling and burnishing")

Mechanik, Vol. 91, No. 8-9 (2018): pages 727-729

DOI: https://doi.org/10.17814/mechanik.2018.8-9.116

\title{
The changes of the workpiece surfaces by hard machining by milling and burnishing
}

\author{
Zmiany powierzchni przedmiotów obrabianych na twardo \\ przez frezowanie i nagniatanie
}

\section{DANIEL GROCHAŁA EMILIA BACHTIAK-RADKA SARA DUDZIŃSKA *}

Today's machines have to be characterized by increasingly better functional and operational properties. The devices should work faster, more efficiently with higher accelerations and at the same time use less energy than it was a few years ago. These requirements apply to the products from the automotive industry, aviation machine tools or machines serving people in everyday life to play or learn. At the same time, a guarantee of long and trouble-free operation is required. In connection with the above, it is increasingly difficult for the technologist to prepare parts that meet the very strict requirements of dimensional and shape accuracy and the state of the geometric structure of the surface (SGP). Also, more and more emphasis is placed on meeting the additional functional requirements of the part surface (hydrophobic or hydrophilic properties, the degree of isotropy or the ability to maintain coatings and lubricants). The paper presents the results of the work aimed at determining the effect of technological parameters of milling and burnishing when treating the surface of parts in the state improved by heat to high hardness. The work focused in particular on the determination of the impact of the strategy of the implemented treatment on changes in the value of SGP indices describing the load-bearing capacity of the surface.

KEYWORDS: hybrid technologies, technological parameters of machining, geometric surface structure, surface bearing capacity

The required functional properties of the surface are given by the technologist on the path of increasingly complicated manufacturing processes. One of the technologies that are willingly used, which allows for the reduction of the surface heights [1-14], is the combination of a volumetric machining with finishing surface plastic finishing. In addition to the advantageous state of SGP (due to a significant reduction in roughness parameters after milling [1-9] or turning [10-13]) and improvement of reflexivity and surface isotropy, a state of stress in the surface layer, favorable from the point of view of fatigue strength, is obtained. parts [1, 11-13].

* Dr inż. Daniel Grochała (daniel.grochala@zut.edu.pl), mgr inż. Emilia Bachtiak-Radka (emilia.bachtiak-radka@zut.edu.pl), mgr inż. Sara Dudzińska (sara.dudzinska@zut.edu.pl) - Zachodniopomorski Uniwersytet Technologiczny w Szczecinie
The final state after a machining operation integrating two treatments (waste treatment with plastic working) depends mainly on the state of SGP obtained as a result of the first treatment, i.e. the chip treatment [14].

The work carried out so far in ITM ZUT in Szczecin confirmed that the state of SGP after chip machining (milling $[1,2])$ can be easily modified by burnishing with two passes - provided a special machining strategy (appropriate trajectory of the burnishing tool in relation to direction of traces left by the cutter).

Advantageous effects can also be obtained with heat-treated materials for significant hardness. Then, burnishing with two passes gives just as good results as using high-value burnishing $F_{\mathrm{b}}$. Such burnishing also ensures longer durability of the ceramic burnishing elements (made of $\mathrm{ZrO}_{2}$ or $\mathrm{Al}_{2} \mathrm{O}_{3}$ ) and is safer in terms of the state of stress generated in the surface layer of the part.

In the literature related to the subject of the work, the application for improving the shape of the bearing curve (Abbott-Firestone) is often requested. Most of the work devoted to this issue, however, focuses on optimizing the set of technological processing parameters (in particular the burnishing force $F_{b}$ ), while the results of studies on the impact of burnishing strategies on the values describing the shape of the load curve are missing.

The aforementioned lack of publication and the interest of the Szczecin team of researchers in the subject of improving the tribological properties of spatial surfaces of such products as injection molds and dies induced scientists to perform appropriate experimental tests.

\section{Experimental research}

The selected high-quality SGP parameters were also included in the tests for improving the properties of the surface bearing curve. Work was carried out on samples made of $\mathrm{X} 160 \mathrm{CrMoV} 121$ material, which were then heat-treated to a hardness of $52 \pm 2 \mathrm{HRC}$. The shaping milling was carried out on the milling center DMG DMU-60 MONOBLOK. A folded toroid mill with six carbon plates was used for machining (for machining hard-to-cut materials RD.X1003 MOT - WTN1205) with a diameter of $d_{p}=10 \mathrm{~mm}$. The crushing with a single-ball hydrostatic burner was carried out on the milling center MIKRON VCE 500; a ceramic burnt ball made of $\mathrm{ZrO}_{2}$ material, diameter $d_{\mathrm{k}}=10 \mathrm{~mm}$, was mounted in the tool. Other technological processing parameters are listed in the table. 
TABLE. Set of technological processing parameters adopted in the experimental design plan

\begin{tabular}{|c|c|c|c|c|c|c|c|c|c|}
\hline Strategy & $\begin{array}{c}\text { Cutting } \\
\text { speed } \\
v_{\mathrm{c}}, \mathrm{m} / \mathrm{min}\end{array}$ & $\begin{array}{l}\text { Depth } \\
\text { of the cutting } \\
\text { layer } a_{\mathrm{p}}, \mathrm{mm}\end{array}$ & $\begin{array}{l}\text { Feed per } \\
\text { revolution } \\
f_{r}, \mathrm{~mm} / \mathrm{rev}\end{array}$ & $\begin{array}{l}\text { Transver } \\
\text { feed }( \\
f_{\mathrm{wt}},\end{array}$ & $\begin{array}{l}\text { al milling } \\
\text { rilling) } \\
\mathrm{nm}\end{array}$ & $\begin{array}{l}\text { Cross feed } \\
\text { at burnishing } \\
f_{\mathrm{wn}}, \mathrm{mm}\end{array}$ & $\begin{array}{l}\text { Burnishing } \\
\text { speed } \\
v_{b}, \mathrm{~mm} / \mathrm{min}\end{array}$ & $\begin{array}{l}\text { Burnishing } \\
\text { power } \\
F_{b}, N\end{array}$ & $\begin{array}{c}\text { The diameter } \\
\text { of the burnishing ball } \\
d_{k}, \mathrm{~mm}\end{array}$ \\
\hline $\mathrm{PO}$ & 110 & 0.5 & 0.6 & $A=0.3$ & $B=0.5$ & 0.02 & 8000 & 800 & 10 \\
\hline $\mathrm{PP}$ & 110 & 0.5 & 0.6 & $A=0.3$ & $B=0.5$ & 0.02 & 8000 & 800 & 10 \\
\hline SK & 110 & 0.5 & 0.6 & $A=0.3$ & $\mathrm{~B}=0.5$ & 0.02 & 8000 & 800 & 10 \\
\hline
\end{tabular}

Three burnishing strategies were selected for the research. The first one was burnishing in a single pass straight to the traces left by the milling cutter (orthogonal strategy - PO). The second strategy was burnishing in two perpendicular transitions, where the first was orthogonal to milling marks (double-perpendicular strategy - PP). The last of the adopted strategies included two mutually perpendicular crossings, both being carried out at an angle of $45^{\circ}$ relative to the milling tracks (skew strategy - SK).

The impact of the strategy was checked for two cases of burnishing during burnishing: $f_{\mathrm{wf}}=0.3$ and $f_{\mathrm{wf}}=0.5 \mathrm{~mm}$. A total of 16 samples were prepared during the tests, including 14 milled and burnished (two samples after milling were left as reference samples).

\section{Surface measurements and preparation of test results}

SGP measurements were carried out in the Surface Topography Laboratory (LTP) of ZUT in Szczecin. For this purpose, a multisensory AltiSurf A520 machine, armed with a CL1 chromatic confocal sensor [15] with an operating range of up to $130 \mu \mathrm{m}$ and a resolution in the optical axis of the 8 $\mathrm{nm}$ instrument was used. The measurements were made on fields with dimensions of $3.0 \times 3.0 \mathrm{~mm}$. The scan resolution was experimentally determined: along the $X$ axis $-0.47 \mu \mathrm{m}$, along the $Y$ axis $-5 \mu \mathrm{m}$; it gave almost 3.8 million mapping points for each surface.

The digital treatment of the collected point cloud and the determination of the stereometric values of the SGP parameters (according to $[16,17])$ were made in the AltiMap PREMIUM 6.2 software.

For each surface scan the collected point cloud was leveled (with the mean plane, approximated by the least squares method), and then the incorrectly collected surface points were removed (threshold values were taken from $0.05 \div 99.95 \%$, while the removed points were set as un-measured values).

Finally, the values of the most popular parameters of constructors and technologists describing the height of the surface - Sa and $S q$ (fig. 1) - and the values of parameters used in describing the surface bearing capacity $[16,17]$ (fig. 2) were determined.

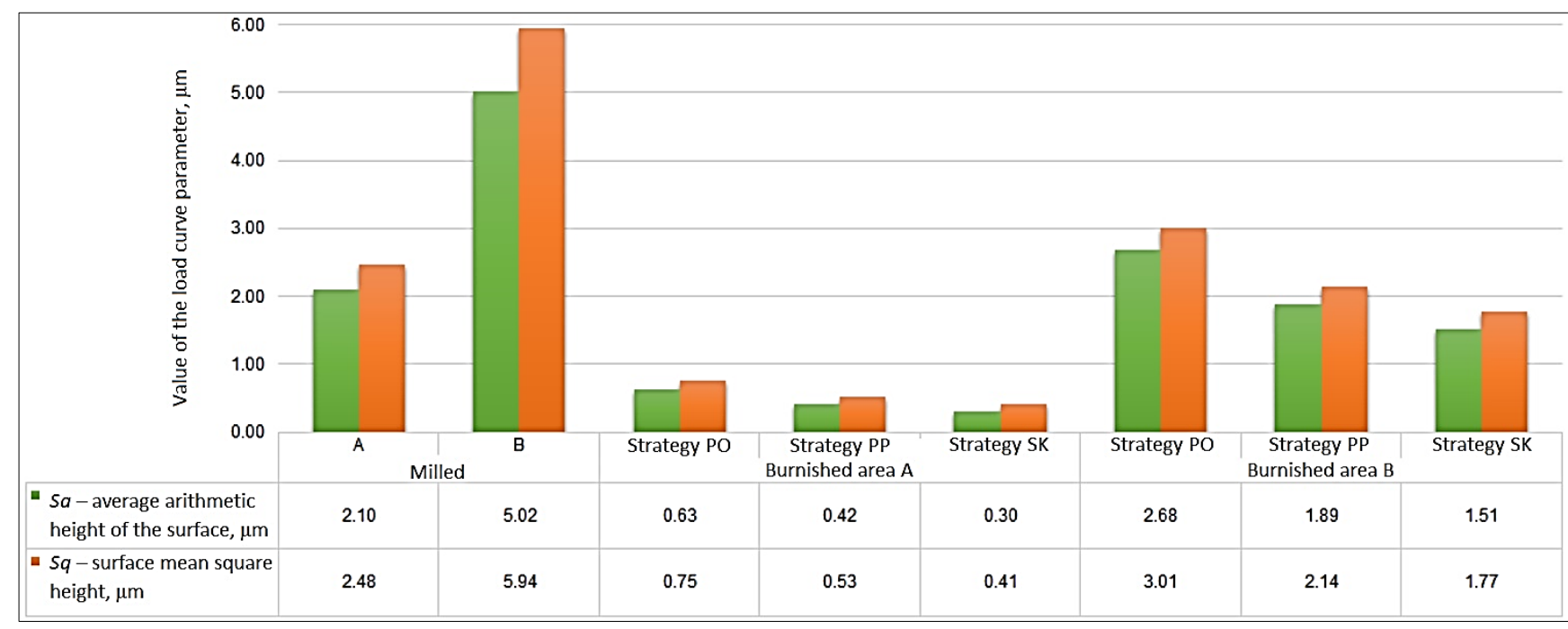

Fig. 1. Values of elevation surface parameters, registered during tests in accordance with ISO 25178

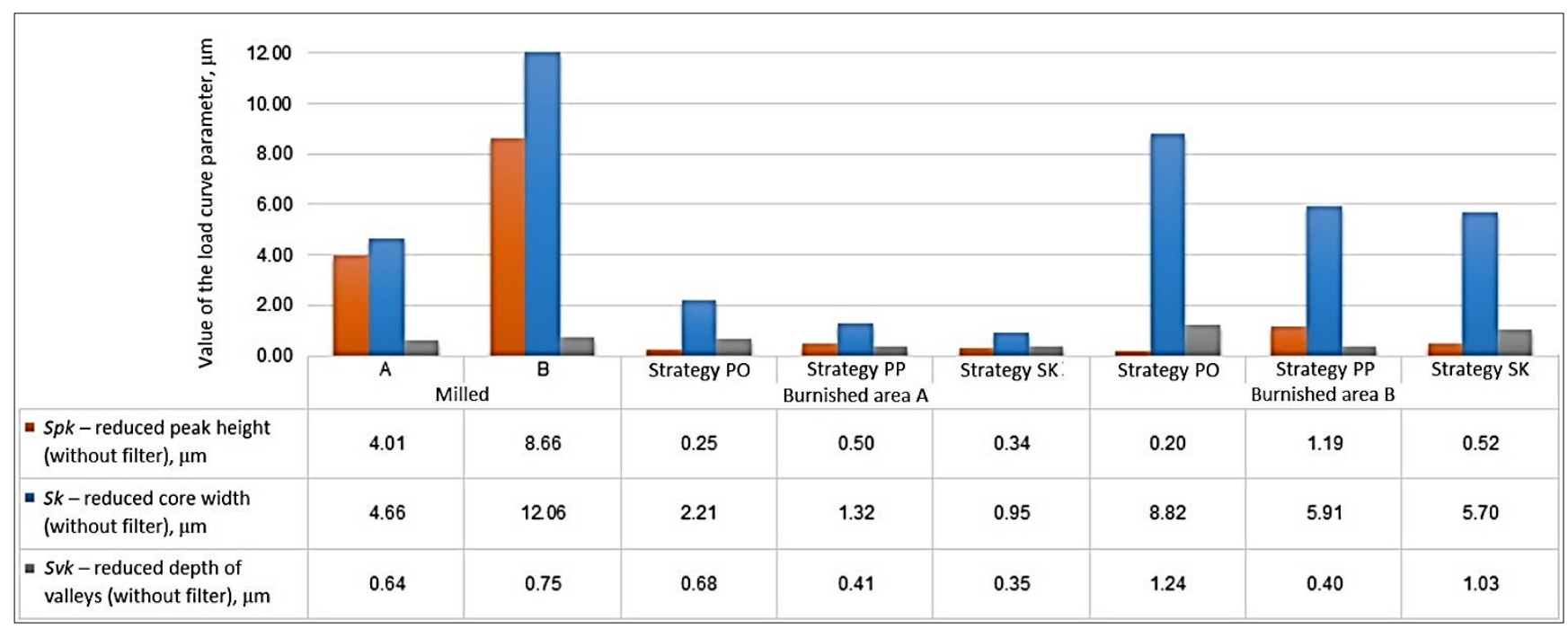

Fig. 2. Values of functional surface parameters, registered during tests in accordance with ISO 25178 


\section{Conclusions}

Based on the experimental tests carried out, it can be concluded that the use of already low burnishing force allows to significantly reduce the height values of the SGP parameters. The efficiency of neutralizing surface unevenness is all the greater, the smaller the inequalities the cutter has left. There is also a visible impact on the strategy of burial. In all cases, strategies with two penetrating transitions were found to be about $40 \div 100 \%$ better than burnishing in one orthogonal transition. The best strategy among those selected for the study was the skew strategy SK - in special cases it allows to reduce the height parameters of surface irregularities even by over $70 \%$. This is very beneficial considering the advantages of integrating milling and burnishing technology on CNC machining centers.

Very interesting conclusions arise from the analysis of the SGP parameters describing the shape of the surface bearing curve. It turns out that burnishing first reduces the high surface peaks, making it more resistant to abrasion. This is clearly evident especially in the case of burnishing of "high" surface irregularities - the resulting plate-au plateau gives a large surface contact area, and at the same time does not change the volume of the core and valleys, thus leaving places where lubricants can be maintained.

In the future, the developed research material will be subjected to tribological tests aimed at practical verification of tribological properties described in the surface load curve.

\section{REFERENCES}

1. Grochała D., Berczyński S., Grządziel Z. "Stress in the surface layer of objects burnished after milling". International Journal of Advanced Manufacturing Technology. 71, 9-12 (2014).

2. Grochała D., Sosnowski M. „Problemy technologii nagniatania powierzchni przestrzennych złożonych na centrach obróbkowych". Mechanik. 1 (2011): pp. 14-18.

3. Lopez de Lacalle L.N., Lamikiz A., Munoa J., Sanchez J.A. "Quality improvement of ball-end milled sculptured surfaces by ball burnishing". International Journal of Machine Tools \& Manufacture. 45 (2005): pp. 1659-1668.

4. Lopez de Lacalle L.N., Lamikiz A., Sanchez J.A., Arana J.L. "The effect of ballburnishing on heat-treated steel and Inconel 718 milled surfaces". International Journal of Advanced Manufacturing Technology. 32, (2007): pp. 958-968.

5. Rodríguez A., López de Lacalle L.N., Celaya A., Lamikiz A., Albizuri J. "Surface improvement of shafts by the deep ball-burnishing technique". Surface \& Coatings Technology. 206 (2012): pp. 2817-2824.

6. Shiou F.J., Chen C.H. "Determination of optimal ball-burnishing parameters for plastic injection moulding steel". International Journal of Advanced Manufacturing Technology. 3 (2003): pp. 177-185.

7. Shiou F.J., Chen C.H. "Ultra-precision surface finish of NAK80 mould tool steel uising sequential ball burnishing and ball polishing processes". Journal of Materials Processing Technology. 201 (2008): pp. 554-559.

8. Shiou F.J., Chuang C.H. "Precision surface finish of the mold steel PDS5 using an innovative ball burnishing tool embedded with a load cell". Precision Engineering. 34 (2010): pp. 76-84.

9. Kalisz J., Żak K., Grzesik W., Czechowski K. "Characteristics of surface topography after rolling burnishing of EM AWAlCu4MgSi(A) Aluminum alloy". Journal of Machine Engineering. 15, 1 (2015): pp. 71-80.

10. Grzesik W., Żak K. "Investigation of technological effects of ball burnishing after cryogenic turning of hard steel". Advances in Manufacturing Science and Technology. 38, 1 (2014): pp. 37-52.

11. Kukiełka L., Kułakowska A., Patyk R. „Numerical Analysis and Experimental Researches of Burnishing Rolling Process of Worpieces with Real Surface". The 13th World Multi-Conference on Systemics, Cybernetics and Informatics, Orlando, Floryda, 2009, pp. 63-68.
12.Kułakowska A., Kukiełka L. "Numerical analysis of influence of surface geometrical structure prepared under burnishing rolling onto the state of strains and stress in product surface layer". Computer Methods in Materials Science. Kraków 2009, pp. 66-71.

13.Patyk R., Kukiełka L. "Optimization of geometrical parameters of regular triangular asperities of surface put to smooth burnishing". The 12th International Conference Metalforming 2008, AGH Kraków, 21-24 September 2008. Steel Research International Special Edition. Vol. 2, 2008. Publishing Company VerlagStahleisen GmbH, ISBN 978-3-514-00745-3, pp. 642-647.

14.Polowski W., Czechowski K., Toboła D., Rusek P., Kalisz J., Janczewski Ł. „Wybrane aspekty obróbki wiórowej jako obróbki poprzedzającej nagniatanie". Monografia VI Szkoły Obróbki Skrawaniem - Obróbka Skrawaniem Efektywne Wytwarzanie. Wrocław 2012, ISBN 978-83-91-917677-7-1, pp. 503-512.

15. Mathia T., Pawlus P., Wieczorowski M. "Recenttrends in surfacemetrology". Wear. 271 (2011): pp. 494-508.

16. ISO 25178-1:2016(en) Geometrical product specifications (GPS). Surface texture: Areal - Part 1. Indication of surface texture.

17.ISO 25178-2 Geometrical product specifications (GPS) - Surface texture: Areal - Part 2. Terms, definitions and surface texture parameters.
Translation of scientific articles, their computer composition and publishing them on the website www.mechanik.media.pl
by original articles in Polish is a task financed from the funds of the Ministry of Science and Higher Education designated for dissemination of science.

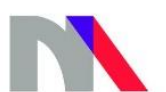

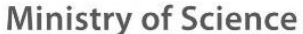

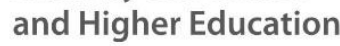

